1. Гудзенко Н.М., Григораш М.В. Облік і місце фінансових результатів у звітності підприємства. Науковий вісник Херсонського державного університету. Сер.: Економічні науки. Вип. 29(2). 2018. Херсон. С. 158-160.

2. Назаренко О.В., Лукаш Р.В. Фінансові результати: сутність та особливості організації бухгалтерського обліку. Інвестиції: практика та досвід. № 22. 2018. C. 19-25.

3. М(С)БО 18 «Дохід»: Стандарт № 929_025 від 01.01.2012. URL: https://zakon.rada.gov.ua/laws/main/929_025 (дата звернення: 22.11.2019).

4. НП(С)БО 1 «Загальні вимоги до фінансової звітності: Положення від 07.02.2013 № 73. URL: https://zakon.rada.gov.ua/laws/main/z0336-13 (дата звернення: 22.11.2019).

5. Панченко I.А. Внутрішня звітність про фінансові результати діяльності у форматі запитів користувачів. Проблеми теорії та методології бухгалтерського обліку, контролю і аналізу. Вип. 2 (23). 2012. С. 253-261.

6. Податковий кодекс України: Кодекс України від 02.12.2010 № 2755-VI URL: https://zakon.rada.gov.ua/laws/main/2755-17 (дата звернення: 22.11.2019).

7. П(С)БО 15 «Дохід»: Положення від 29.11.1999 № 290 URL: https://zakon.rada.gov.ua/laws/main/z0860-99 (дата звернення: 22.11.2019).

8. Про бухгалтерський облік та фінансову звітність в Україні: Закон України від 16.07.1999 р. № 996-XIV. URL: https://zakon.rada.gov.ua/laws/show/996-14 (дата звернення: 22.11.2019).

9. Прохар Н.В., Ночовна Ю.О. Облік доходів, витрат і фінансових результатів: проблеми теорії та практики: монографія]. Полтава: РВВ ПУЕТ. 2011. 257 с.

10. Слободняк И.А. Система форматов внутренней бухгалтерской управленческой отчетности. Известия ИГЭА. № 4 (72). 2010. С. 32-37.

*УДК 351.84

Шубалий О.М., д.е.н., професор

Андрусик I.O.

Луцький національний технічний університет

\title{
НАПРЯМИ ВДОСКОНАЛЕННЯ СИСТЕМИ НАДАННЯ СОЦІАЛЬНИХ ДОПОМОГ НАСЕЛЕННЮ В УКРАЇНІ
}

У статті проведено оцінку стану і обгрунтовано перспективні напрями вдосконалення системи надання допомог населенню на прикладі України.

Ключові слова: соціальний захист, доходи населення, соціальні допомоги, соціальне забезпечення, допомога, населення, країна.

* Шубалий О.М., Андрусик I.О. 


\section{Shubalyi O., Andrusyk I. \\ WAYS TO IMPROVE THE SYSTEM OF PROVIDING SOCIAL ASSISTANCE TO THE POPULATION IN UKRAINE}

The need for social protection research to address social problems in the country is driven by an unstable situation. Effectiveness of development of social protection of the population, reproduced in the level of life of citizens and social stability in society. Social assistance plays an important role in the social well-being of Ukrainian citizens.

The purpose of the study is to study trends in indicators and to substantiate recommendations on ways to improve the system of providing social assistance to the population in Ukraine.

Explaining the essence of social benefits is particularly important in the complex situations that have arisen today, as social protection is a means of preserving stability and harmony in a society, an instrument through which the state can influence people's lives.

The dynamics of changes in social security expenditures from the state budget has been studied, according to the data we can see that the actual amount of expenditures is increasing by $55 \%$ in 2018 , but nevertheless, their share in $\%$ of the country's GDP has decreased by $2.1 \%$, respectively, over the last three years. talks about reducing the effectiveness of this article costs. Which suggests the need for further research and prevention of a similar situation.

An assessment of the effectiveness of providing social assistance to the population has shown that there are many problems and imperfections that impede the proper functioning of the social protection system. The biggest drawback is the insufficient level of security of the population in order to solve a significant part of the existing problem, and it is possible to offer active involvement of citizens in work.

The implemented social protection policy, which provides assistance to the population every year, is undergoing significant changes, therefore improvements and additions are necessary measures in its activity. The biggest problem that currently exists is the inconsistency of social standards with the real situation, in these circumstances, the inhabitants of our country are unable to meet their needs and high standard of living.

Key words: social protection, income of the population, social benefits, social security, assistance, population, country.

\section{Шубалый А.М., Андрусик И.О.}

СПОСОБЫ УСОВЕРШЕНСТВОВАНИЯ СИСТЕМЫ ПРЕДОСТАВЛЕНИЯ СОЦИАЛЬНОЙ ПОМОЩИ НАСЕЛЕНИЮ УКРАИНЫ

В статье проведена оценка состояния и обоснованно перспективные направления совершенствования системы предоставления пособий населению на примере Украины.

Ключевые слова: социальная защита, доходы населения, социальные пособия, социальное обеспечение, помощь, население, страна. 
Постановка проблеми у загальному вигляді і їі зв'язок 3 важливими науковими та практичними завданнями. Необхідність дослідження соціального захисту щодо вирішення соціальних проблем в країні обумовлена нестабільною ситуацією. Ефективність розвитку соціального захисту населення, відтворена у рівні життя громадян та соціальній стабільності в суспільстві. Соціальна допомога відіграє важливу роль у соціальному добробуті громадян України. Важливість соціальної допомоги полягає в тому, що кожен $з$ жителів України має право отримати фінансову підтримку, що коригується у розмірі, не меншому, ніж показник прожиткового мінімуму, якщо з незалежних на то причин його щомісячний дохід не відповідає мінімальним стандартам. Рівень соціальних допомог населенню значною мірою залежить від рівня матеріальної забезпеченості населення. Тому виникає необхідність проведення додаткових досліджень щодо особливостей нарахування соціальних допомог на рівні держави.

Аналіз останніх досліджень, у яких започатковано вирішення проблеми. Досліджуване питання розкрите в працях багатьох вітчизняних і зарубіжних науковців, зокрема таких як А. Дудкіна, В. Панченко, М. Бойко, С. Кузьменко, Д. Кожевніков, Ж. Анселен та інших вчених [2-7]. Відзначивши значний внесок даних науковців у досліджуваному питанні, слід зауважити, що обгрунтування ефективного застосування соціальних допомог у системі соціальної політики щодо вирішення соціальних проблем в країні вимагає подальших досліджень.

Цілі статті. Мета дослідження полягає у вивченні тенденцій зміни показників та обгрунтуванні рекомендацій щодо напрямів вдосконалення системи надання соціальних допомог населенню в Україні.

Виклад основного матеріалу дослідження з повним обгрунтуванням отриманих наукових результатів. Ступінь здійснення соціальних функцій державою можна оцінити, вивчивши динаміку загальних видатків на соціальний захист в Україні (рис. 1). 
"Економічні науки". - Серія "Облік і фінанси". - Випуск 16 (61). - 2019.

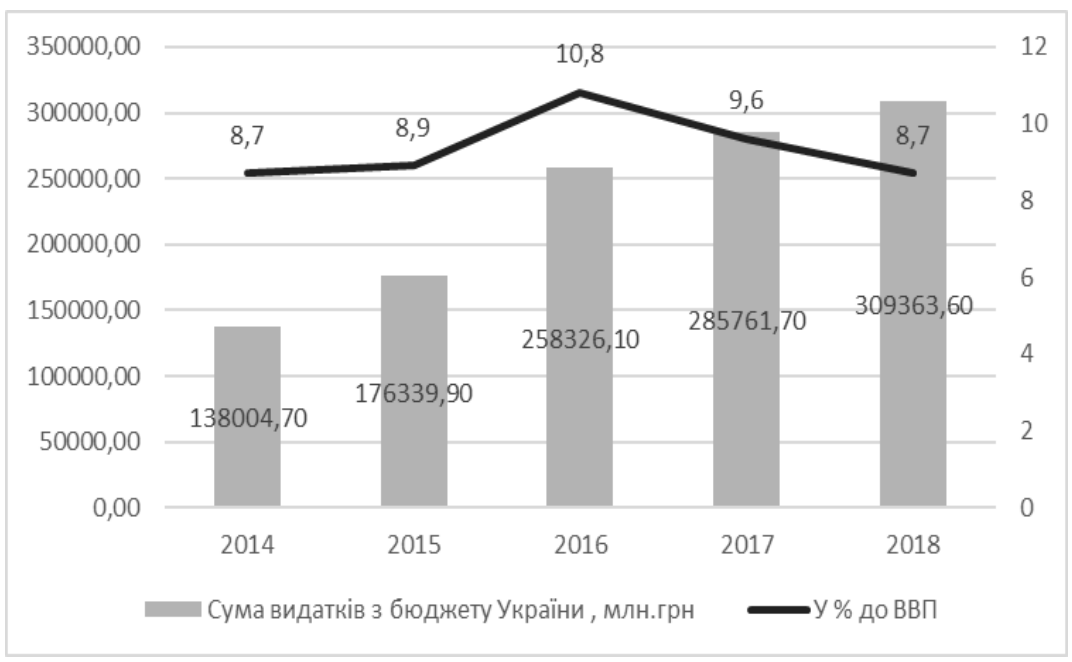

Рис. 1. Динаміка загальних видатків на соціальний захист та у \% до ВВП, в Україні за 2014-2018 р. (побудовано автором на основі джерела [1])

Спостерігаємо зростання видатків на соціальний захист та соціальне забезпечення, а саме 3138004,7 млн грн у 2014 році до 309363,6 млн грн у 2018 році, або відповідно на 55\%. Як бачимо, що попри збільшення суми видатків, їх рівень у \% до ВВП у 2016 році почав зменшуватись, а саме на $2,1 \%$ у 2018 році в порівнянні 3 2016 роком. Дана співвідношення чітко нам показує, що рівень соціальних допомог протягом останніх років зростав лише у відносному виражені, коли фактично його ефективність зменшувалась. Попри щорічне збільшення видатків бюджету на соціальну сферу, рівень соціального захисту населення залишається на низькому рівні.

За результатами детальнішого порівняльного аналізу зміни загальних доходів та питомої ваги соціальних допомог в Україні за 2013-2017pp. (рис. 2) можна зробити висновок про те, що загальне зростання доходів (з 1478073 млн. грн. у 2013 році до 2652082 млн. грн. у 2017 році, або загалом майже у 2 рази) супроводжується пос- 
тійним спаданням показника питомої ваги соціальних допомог у загальних доходах (з 39,7\% у 2013 році до 33,4\%. у 2017 році).

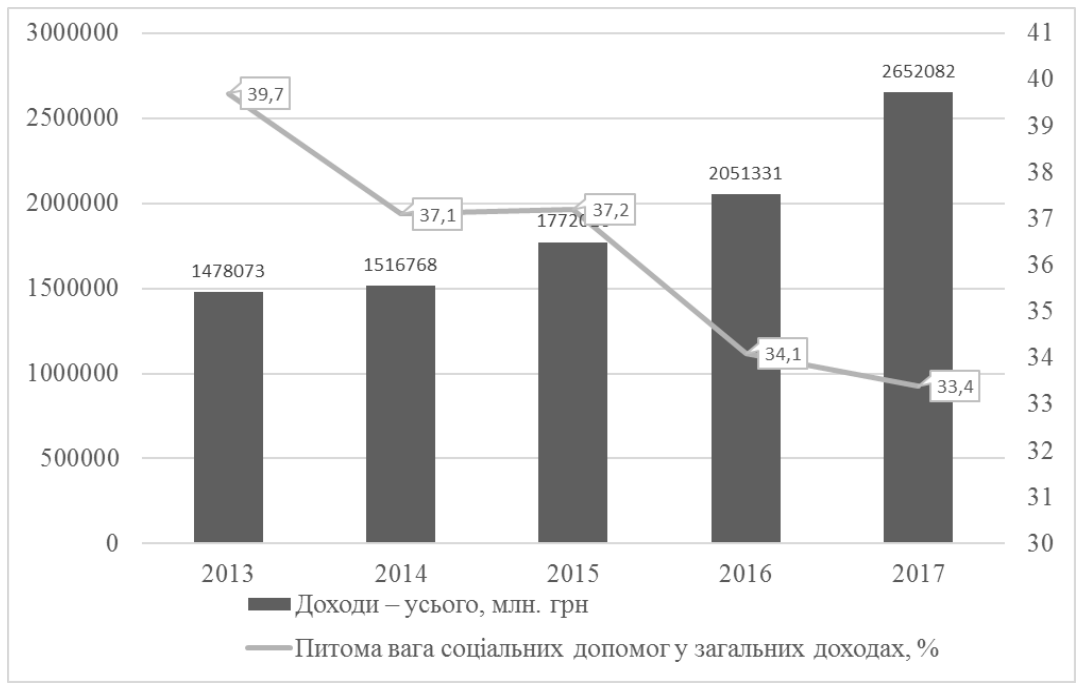

Рис. 2. Порівняльний аналіз зміни загальних доходів та наявного доходу у розрахунку на одну особу в Україні за 2013-2017 pp.

Загалом можна позитивно оцінити тенденції постійного прискореного зростання загальних доходів населення, а також і зменшення показника питомої ваги соціальних допомог за 2013-2017 pр. Дана ситуація говорить про зростання рівня життя населення, оскільки громадяни країни кожного року самостійно збільшують ступінь забезпеченості, з меншим \% соціальних допомог у загальних доходах населення України. Особливо важливо, що різкий приріст цих показників спостерігався саме у 2016 році, що пов'язано з різким зростанням соціальних гарантій. Хоча певним поясненням таких змін може стати наростання інфляційних процесів, що призводять до зростання лише номінальних доходів.

Ще одним пріоритетом $\epsilon$ - захистити найбільш вразливих громадян та забезпечити безпеку, соціальну справедливість. Перш за все, це реалізація соціальних ініціатив, спрямованих на захист 
дітей $з$ особливими потребами та забезпечення нормальних умов життя та розвиток.

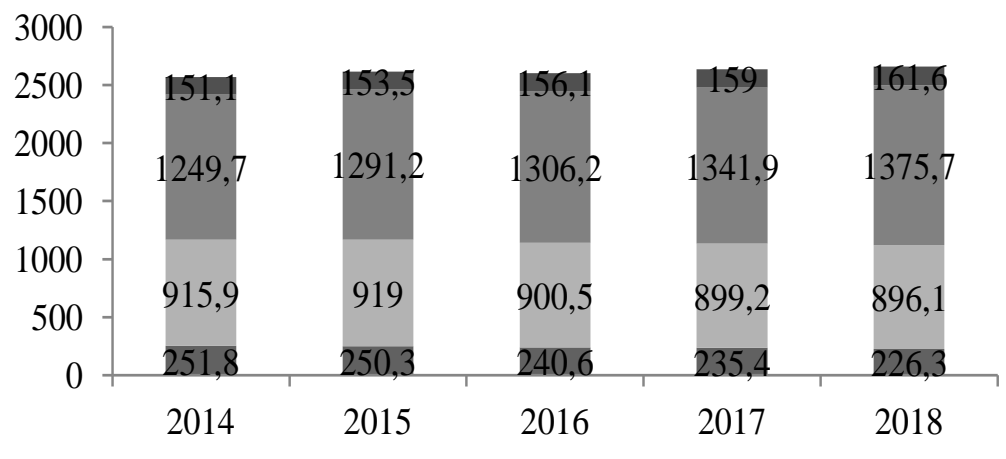

Рис. 3. Динаміка зміни кількості осіб з інвалідністю в Україні за 2014-2018 рр.(побудовано автором за даними [1])

Загалом протягом аналізованого періоду кількість інвалідів практично залишалась не змінною. Найбільше значення було досягнете у 2018 році за рахунок збільшення кількості інвалідів III групи та кількості дітей-інвалідів. Це значною мірою було пов'язано 3 воєнними діями на Сході нашої країни та погіршенням екологічної ситуації. Протягом останніх років спостерігається тенденція до зменшення кількості інвалідів II та I групи, а натомість зростає кількість інвалідів III групи, у 2018 році їх кількість збільшилась на 126 тис осіб. Кількість дітей-інвалідів не великими темпами, але має тенденцію до збільшення.

Згідно наведених даних у табл. 1, протягом останніх 5 років кількість одержувачів соціальних допомог, які не мають права на пенсію, зросло на 63927 осіб, або на 49\%. Дана тенденція є негативною, оскільки збільшується сума виплат на допомоги, а також збільшується навантаження на державний бюджет. Це говорить про те, що населення України все більше хворіє, а тому не має можливості заробити страховий стаж, аби потім отримувати пенсію по віку. 
"Економічні науки". - Серія "Облік і фінанси". - Випуск 16 (61). - 2019.

Таблиця 1

Державна соціальна допомога особам, які не мають права на пенсію, та інвалідам протягом 2014-2018 pp.

\begin{tabular}{|c|c|c|c|}
\hline Рік & $\begin{array}{c}\text { Кількість } \\
\text { одержувачів, } \\
\text { осіб }\end{array}$ & $\begin{array}{c}\text { Загальна сума при- } \\
\text { значеної місячної } \\
\text { допомоги з ураху- } \\
\text { ванням надбавок, } \\
\text { підвищень та сум } \\
\text { індексації, тис.грн. }\end{array}$ & $\begin{array}{c}\text { Середній розмір приз- } \\
\text { наченої місячної допо- } \\
\text { моги з урахуванням } \\
\text { сум індексаціїень грн. }\end{array}$ \\
\hline 2014 & 65569 & 62268,14 & 949,66 \\
\hline 2015 & 77092 & 82086,13 & 1064,92 \\
\hline 2016 & 79843 & 97582,3 & 1222,27 \\
\hline 2017 & 98255 & 142038,9 & 1445,61 \\
\hline 2018 & 129496 & 195689,1 & 1511,16 \\
\hline
\end{tabular}

Примітка. Побудовано автором на основі даних [1].

Також бачимо, що середній розмір призначеної місячної допомоги у 2018 році становить1511,16 грн, що на 561,5 грн більше, або на $37 \%$ більше ніж у 2014 році.

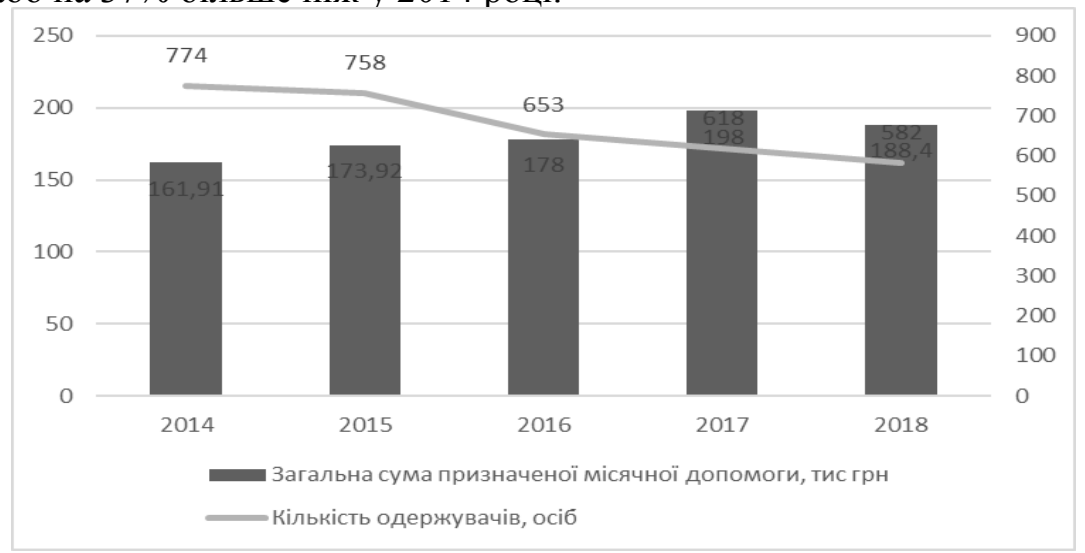

Рис. 4. Співвідношення суми призначеної державної допомоги та кількості їх одержувачів в Україні за 2014-2018 рр (побудовано автором за даними [1]) 
Бачимо, що з 2014 року сума призначеної місячної допомоги поступово збільшувалась включно до 2017 року, іiі сума становила 198 тис грн., що на 36,09 тис грн. більше ніж у 2014 році, а у 2018 році, вона зменшилась на 9,6 тис грн. Протягом аналізованого періоду, спостерігаємо тенденцію зменшення кількості одержувачів на 192 особи. 3 наведених даних бачимо, що сума допомоги за останні роки збільшилась попри зменшення кількості іiі отримувачів, що говорить про збільшення середнього розміру місячної допомоги та збільшення рівня адресності в наданні даної допомоги.

Слід зазначити, що Україна має резерв для пом'якшення впливу соціальних реформ. Головним рішенням даної ситуації має бути виведення економіки з тіні та підвищення платіжної стійкості. I це, перш за все, проблема ефективності податкової системи в державі.

Висновки. Пояснення суті соціальних допомог $є$ особливо важливим при складних ситуаціях, які утворилися нині, оскільки соціальний захист населення є засобом збереження стабільності та гармонії в суспільстві, знаряддям, за допомогою якого держава може впливати на життя людей.

Вивчено динаміку змін видатків на соціальний захист 3 державного бюджету, згідно даних бачимо, що фактичний розмір видатків збільшується на 55\% у 2018 році, але попри це частка їх у \% до ВВП країни протягом останніх трьох років зменшується відповідно на 2,1\%, що говорить про зниження ефективності даної статті видатків. Що говорить про необхідність подальших досліджень та попереджень аналогічної ситуації.

Оцінка ефективності надання соціальних допомог населенню показала, що існує багато проблем та недосконалостей, які перешкоджають нормальному функціонуванню системи соціального захисту. Найбільшим недоліком виступає недостатній рівень забезпеченості населення, аби вирішити значну частину наявної проблеми, можна запропонувати активне залучення громадян до праці.

Впроваджена політика соціального захисту, щодо надання допомог населенню з кожним роком переживає значні зміни, тому вдосконалення та доповнення $є$ необхідними заходами у іiі діяльно- 
"Економічні науки". - Серія "Облік і фінанси". - Випуск 16 (61). - 2019.

сті. Найбільшою проблемою, яка існує на даний час є невідповідність соціальних стандартів реальній ситуації, за даних обставин жителі нашої країни не можуть задовольнити свої потреби та високий рівень існування.

1. Головне управління статистики у Волинській області. URL: http://www.lutsk.ukrstat.gov.ua/ (дата звернення: 22.11.2019).

2. Дудкин А. С. Социальная помощь как форма общественных отношений (социально философский аспект). Пенза, 2006. 213 с.

3. Панченко В. Ю. О понятии социальной помощи в современном обществе. СОЦИС. 2012. №5. С.13-18.

4. Бойко М. Д. Право соціального забезпечення України: навч.посіб. Київ: Олан, 2004. 312 c.

5. Кузьменко С. Г. Соціальна допомога в системі державних органів управління. Теорія та практика державного управління. 2011. №3. С.1-5.

6. Кожевников Д. Е. Государственная социальная помощь малоимущим гражданам: правовые вопросы: автореф. Екатиринбург, 2010. 28 с.

7. Анселен Ж. Франция: социальные услуги. Соціальна робота в Україні: теорія і практика. 2013. № 1-2. С. 204-219. 